\title{
Reflections on the theory of "silver bullet" octreotide tracers: implications for ligand-receptor interactions in the age of peptides, heterodimers, receptor mosaics, truncated receptors, and multifractal analysis
}

Roy Moncayo $0^{1,2}$

\begin{abstract}
The classical attitude of Nuclear Medicine practitioners on matters of peptide-receptor interactions has maintained an intrinsic monogamic character since many years. New advances in the field of biochemistry and even in clinical Nuclear Medicine have challenged this type of thinking, which prompted me to work on this review. The central issue of this paper will be the use of somatostatin analogs, i.e., octreotide, in clinical imaging procedures as well as in relation to neuroendocirne tumors. Newly described characteristics of G-protein coupled receptors such as the formation of receptor mosaics will be discussed. A small section will enumerate the regulatory processes found in the cell membrane. Possible new interpretations, other than tumor detection, based on imaging procedures with somatostatin analogs will be presented. The readers will be taken to situations such as inflammation, nociception, mechanosensing, chemosensing, fibrosis, taste, and vascularity where somatostatin is involved. Thyroid-associated orbitopathy will be used as a model for the development of multi-agent therapeutics. The final graphical summary depicts the multifactorial properties of ligand binding.
\end{abstract}

Keywords: Michaelis-Menten, ligand, receptor, GPCR, somatostatin, octreotide, homodimers, heterodimers, receptor mosaics, multifractal analysis, morphogens, morphostats

\section{The setting}

In past issues of the European Journal of Nuclear Medicine and Molecular Imaging, some articles have pointed out puzzling aspects concerning ligand-receptor interactions. Rolleman et al. have documented the situation of an apparent positive cooperation between non-labeled somatostatin (SST) analogs and a radio-labeled compound in vivo [1]. A similar situation of increased tracer binding in the presence of $100 \mu \mathrm{g}$ of cold octreotide had been shown earlier by Hofland [2]. These data seem to contradict some views of ligand-receptor interactions which constitute the basis of the biochemical and

\footnotetext{
Correspondence: Roy.Moncayo@i-med.ac.at

${ }^{1}$ Department of Nuclear Medicine, Medical University of Innsbruck, Innsbruck, Austria
}

Full list of author information is available at the end of the article pharmaceutical work that is daily applied in Nuclear Medicine imaging.

The aim of this short review is to assemble recently available information on the physiological roles of somatostatin and similar substances, on modern concepts on receptors, and on binding modulators, in order to attempt to arrive at a new level of interpretation that will put a new light on scintigraphic and binding data. These data should also be a guiding complement for new peptide tracers being developed [3].

Introduction: the basics of receptor binding and the use of octreotide

The concepts regarding receptor function have been accommodated over time to a reductionist model that ideally considers one ligand and one receptor. The basic theories behind were developed between 1900 and 1920

\section{SpringerOpen ${ }^{\circ}$}

(C) 2011 Moncayo; licensee Springer. This is an Open Access article distributed under the terms of the Creative Commons Attribution License (http://creativecommons.org/licenses/by/2.0), which permits unrestricted use, distribution, and reproduction in any medium, provided the original work is properly cited. 
[4-7]. In 1956, the concept of the ability of a drug to induce an effect after binding-efficacy-was introduced by Stephenson [8]. This way of thinking fits into the metaphor of the "silver bullet", i.e., a straightforward solution thought to have outmost effectiveness (or efficacy). Based on the theories of an allosteric receptor model, Thron discussed in 1973 the interplay between agonists and antagonists [9]. These theorems have found acceptance in the field of Nuclear Medicine [10] and have been the basis for experimental and clinical work extending into the modern field of peptide therapy using SST analogs (SSA) such as octreotide and lanreotide.

The most known theorem regarding ligand interactions is the Michaelis and Menten reaction [6], defined as $v=(V \max S) /\left(S+K_{\mathrm{m}}\right)$. This equation has been revised recently from the stand point of fractal kinetics [11] in order to attempt to reach a higher level of understanding of the biochemical reactions found intracellularly [12]. Aranda et al. state: "Classical enzyme kinetics, which assumes the Michaelis-Menten paradigm with perfectly mixed reactants and homogeneous media, is strongly limited for applications including intracellular enzyme reactions. A major difference between a diluted enzymatic system and that found inside the cell is the high mechanical and rheological complexity of the cytoplasmic environment that produces anomalous diffusion phenomena seriously affecting enzyme kinetics of biochemical pathways" [13]. By a simple process of logical deduction, we should then expect to have in vivo a highly complex whole body situation when different types of tissues are being examined through scintigraphy with octreotide or other tracers in general.

The basis for the development of SST receptor (SSTR) imaging can be traced back to the research work done by Roger Guillemin [14,15]. Somatostatin was first described in 1973 by Brazeau et al. [16]. The same communication reported the bioactivity of a synthetic replicate. From the industrial point of view, researchers advanced the development of analogs quite soon after the discovery of somatostatin. The initial work was based on peptide chemistry by which the SST sequences related to peptide binding were identified [17-19]. In order to validate the binding ability, ligand binding assays were established [20]. On clinical grounds, one of the first applications of unlabelled octreotide was the treatment of acromegaly [21]. In the field of Nuclear Medicine, radioactive-labeled octreotide tracers have been in clinical use since the 1990s [22,23] becoming an established diagnostic procedure [24]. The characteristics of natural and synthetic analogs in relation to receptor internalization, as well as the conformational changes due to labeling with Yttrium or Gallium have been recently summarized by Hofland and Lamberts [25], and by Deshmukh et al. [26], respectively.
It has to be mentioned that some of the in vitro research with SSA in relation to neuroendocrine tumors (NET) is based on the use of pancreatic carcinoma cell lines which had been chemically induced by azaserine [27]. The histological picture of these tumors varies from "poorly differentiated solid carcinomas to well-differentiated variants which form acini" (rat CA20948 tumors) [27]. Due to the diversity of forms of NET, one should be cautious when extrapolating results from these in vitro observations [28]. Unfortunately this cell line is still in use in 2011.

At the present time, a high level of technological development has been reached by combining $\mathrm{Ga}^{68}$ labeled SST analogs and whole body PET-CT scanning [29] which now delivers more information about tracer distribution. In view of this advanced imaging situation with a higher level of molecular resolution, it is important to review the physiology related to SSTR imaging in order to come to an adequate interpretation.

\section{Somatostatin receptors in fibrosis, vascularity, inflammation, and taste}

Since the 1990s, one main application of SSTR imaging is in the diagnosis of neuroendocrine tumors [23]. At the time these tumors are diagnosed, there is usually clinically evident hepatic involvement. One yet unexplained biological characteristic of carcinoids is that to tend to develop fibrosis [30,31]. It should be kept in mind that liver fibrosis is accompanied by SSTR expression [32]. The role of stromal fibrosis in connection with octreotide uptake has been described by Öhrwall et al. [33]. Lebtahi et al. have shown the influence of pulmonary tissue fibrosis on octreotide uptake [34]. It follows that scintigraphic evidence of octreotide uptake might be an expression of fibrosis, which unfortunately cannot be distinguished from tumor. In a disease characterized by fibrosis, i.e., fibrous dysplasia, Chen et al. documented octreotide uptake which remained unchanged even after treatment with Sandostatin ${ }^{\circledR}$ [35]. Besides fibrosis, another cause for apparent increase of binding sites in a tumor might be in relation with blood vessels [36]. This same property has been praised as a therapeutical option of somatostatin, i.e., that of being anti-angiogenic [37,38].

Experimental studies in macaques conducted by Guo et al. [39] have demonstrated the pattern of physiological development and expression of SST in the intestinal tract. The animals showed expression in mucosal crypts and as well as in the myenteric nerve plexus. Concomitant to this development the concentration of SST in the liver declined. Deficiency of SSTR2 can alter the mesenteric sensitivity of afferent nerves upon distention, i.e., mechanosensing, or acid exposure, i.e., chemosensing [40]. In addition, SST containing neurons can be found in the enteric mucosa [41]. Under experimental 
fasting conditions, the number of SSTR can diminish and return to normal after refeeding [42].

Recently Gonkowski and Całka [43] have demonstrated a modulation of SST immunoreactivity in the nervous structures of the porcine descending colon under experimental pathological conditions. In situations of intestinal inflammation, one can find changes in the concentration of SST as well as of SSTR [44]. Intestinal inflammation can be worsened when SSTR are not present [45]. In other words, these findings imply that a functioning SST system seems to be important in the control of intestinal inflammation [46].

In view of these data, we should ask ourselves: is there a link between intestinal inflammation and carcinoids? Recent studies have indeed delivered evidence relating both processes. West et al. have shown that carcinoids are 15 times more common in patients with Crohn's disease [47]. In a similar way, Grassia et al. have analyzed the setting of ulcerative colitis [48] and proposed that long-standing inflammation could induce changes towards tumor development. Another interesting link between inflammation and carcinoids has been provided by Sciola et al. [49]. The authors documented that high levels of chromogranin A, a marker of neuroendocrine tumors, can occur in patients with inflammatory bowel disease. In a more general way, one has to consider the interactions of the enteric nervous system with the immune system [50] and situations of intestinal inflammation [51,52]. In an attempt to extrapolate experimental results, Corleto has recently summarized data that deals with SSTR knockout mice, which he believes could be of use for a better understanding of gastrointestinal tract functions and SST [53].

Keeping in mind the initial descriptions of SST in the CNS as well as in GI physiology, it should not surprise us that SST together with other peptides can be involved in visceral sensations such as taste [54]. In addition, homologies between taste receptors and the sequence of SST and opiate receptors have been described [55]. The relevance of this homology will be discussed in the section of heterodimers.

\section{Somatostatin in nociception and its relation to mechanosensing}

A series of studies have documented the relation between SST and nociception as well as with counterregulation in inflammatory situations [56-61]. Changes in the expression of SSTR can be involved in alterations of chemical sensitivity as well as of mechanosensing in afferent mesenteric nerves [62]. Modulation of pain transmission has a complex circuitry which includes SSTR [63]. During the sensitization of nociceptors it has been demonstrated that SST interacts with the vanilloid receptor TRPV1 [64]. The family of vanilloid receptors is involved in mechanosensory conduction [65-68]. $\mu$ -
Opioid receptor activation can modulate thermal hypersensitivity associated with tissue inflammation through the TRPV1 channels [69]. It is interesting to note that in experimental pulp inflammation both SST and opioid levels are found to be locally increased [70]. While these actions might seem to be unrelated to SSTR, a later section dealing with receptor dimerization will bring more light into this issue. Taking that SSTR expression is related to inflammation and nociception in the surroundings of a gastrointestinal tumor, one could expect that some of tracer binding patterns might be related to these processes.

Already in 1990, in the article by Lamberts et al. on the use of iodine-labeled octreotide [71] an anti-nociceptive action of unlabelled short-acting octreotide was described. In 1991 a similar property was described for a long-acting somatostatin analog [72]. A newer SSA, vapreotide, has also been characterized as being antinociceptive [73].

\section{Octreotide scanning in thyroid-associated orbitopathy-what} can we still learn?

In previous studies at the Medical University of Innsbruck we have been involved in the use of octreotide scanning for the evaluation of the inflammatory components of thyroid-associated orbitopathy (TAO) $[74,75]$. Recently, we have been able to describe musculoskeletal components in this disease based on scintigraphic data [76]. While SSTR imaging was positive in TAO patients, the use of cold Sandostatin ${ }^{\circledR}$ did not fulfill the expectations of clinicians and patients. Based on the rather disappointing approaches with immune modulators for the treatment of TAO, we have recently started to apply a different diagnostic and therapeutic approach. By applying diagnostic concepts of TCM, one can characterize these patients as being Qi deficient. This clinical diagnosis coincides with experimental data from Liu et al. who used the herbal formulation Sijunzi (containing Panax ginseng, Poria cocos, Atractylodes macrocephala, and Glycyrrhiza uralensis [77]) in order to treat experimental Qi deficiency [78]. This treatment was able to lower the levels of SST in the colon mucosa.

In $\mathrm{TAO}$, we have started to use a multi-agent herbal preparation based on the use of Western herbs [79]. The formulation used for TAO patients includes Ruta graveolens [80], Anemone pulsatilla, Hypericum perforatum, Serenoa serrulata, Schisandra chinensis [81], Ophiopogon japonicus, Glycyrrhiza glabra, and Zingiber officinale [79]. Hypericum, first described in 1975 [82], can affect the sub-cellular localization of the retinoid $\mathrm{X}$ receptor [83] and acts also as antidepressant and antiinflammatory [84] also through interaction with the CRH-1 receptor [85]. Due to interactions of Hypericum with hepatic metabolism of drugs [86], it is not advisable to administer it together with other pharmaceuticals. 
However, an important action of Hypericum is that of preventing inflammation related fibrosis [87]. Serenoa has been mostly characterized for its use in benign prostate hypertrophy [88]. Schisandra can positively influence the glutathione levels and thus achieve antioxidative effects [89] while at the same time it protects from proteoglycan degradation [90]. The pregnane X receptor can also be activated both by Schisandra and Glycyrrhiza [91]. Ophiopogon has anti-inflammatory properties [92,93]. Finally, Zingiber can inhibit platelet aggregation and has anti-inflammatory properties [94-97]. Translating this approach into treatment terms we can describe it as a multi-agent multi-target strategy. The reader might ask now, how can this knowledge be used in Western medicine? Roth and collaborators have published several articles dealing the investigations of the receptorome, which is the portion of the proteome encoding receptors [98]. Based on this principle they have been able to identify ligands from psychoactive plants that interact with the receptorome [99]. This is a multi-agent multi-target environment of real life. Sucher has recently presented an extensive analysis of herbs for neuroprotective use which were also investigated under a multi-component multi-target approach [100]. Straube et al. have recently proposed the use of multitarget therapeutics for treating headache [101].

While the departing point of this article was to understand the characteristics of scintigraphic studies with SST analogs, we should be aware that medicinal herbs, and potentially nutrients also, can interact with peptide hormones in such a way as to increase the endogenous levels of SST [102-109]. Similar actions, i.e., raising SST levels, can also be observed for omeprazole [110], a drug which is also used in the treatment of carcinoids [111].

\section{Time to think over-somatostatin is not alone-urotensin,}

\section{cortistatin, and somatostatin}

In 1995, two independent research groups discovered a new putative neuropeptide receptor called SENR $[55,112]$. This was followed by the identification of urotensin as the endogenous ligand for SENR (GPR14) [113]. Quite recently, an interaction of urotensin II and of urotensin II-related peptide with SSTR 2 and 5 has been described [114]. Recent data has also confirmed the relationship between SSTR genes and those of UII/ URP which are now viewed as a super family [115]. Truncated SSTR have been recently described in rodents [116]. Neuronostatin, a peptide contained in the SST gene, has been also described quite recently [117]. New physiological relations can be expected to emerge for SST and corstistatin due to similar distribution patterns in tumors $[118,119]$. Another aspect of SST-cortistatin receptors is the association of the cortistatin MrgX2 receptor to nociception [120,121], thus complementing the functions of SST which were described above. Cortistatin has not only similarities with the receptor binding sequence of SST but this also applies to the SST analogs octreotide and lanreotide [122]. The initial descriptions of cortistatin were made by de Lecea et al. [123] followed by Fukusumi et al. [124]

The modern language of receptors: mosaics and dimers, RAMPS, and arrestins

Our medical and biochemical training has told us that one correct ligand interacts with one correct receptor. While it might be correct for in vitro situations where purified receptors are being used, the biological environment contains dynamic structures. Early publications on receptor cooperativity were centered on receptor systems such as the cardiac muscarinic receptors [125]. In this setting Wreggett and Welss identified receptor moieties with an apparent molecular mass of 60-75 kDa, as well as 190 and $240 \mathrm{kDa}$. These last two species were interpreted as homotrimers and homotetramers, respectively. In addition the eluted receptors were accompanied by a mixture of guanyl nucleotide-binding proteins (G-proteins) [125].

The SSTR belongs to the group of G-protein coupled receptors (GPCR). In GPCR, activation of $G$ proteins is induced by receptor-effector coupling [126]. In 1998, Gouldson et al. presented theoretical and experimental data regarding the hypotheses of receptor dimerization based on work with the models of the beta2-adrenergic receptor [127]. They concluded that two processes were important in GPCR activation namely dimerization and domain swapping. Non-ligand receptor activation, however, can also be achieved through receptor-independent activators of G-protein signaling [128].

Another nomenclature for GPCR is that of the seventransmembrane helical receptors (7TM). Several articles have described characteristics of this family of receptors $[126,129,130]$. The five main types of families can be summarized by the term GRAFS which includes Glutamate, Rhodopsin, Adhesion, Frizzled/taste2, and Secretin receptors [131,132]. GPCR have the property of forming dimers, either homo- or heterodimers [133,134]. This type of association has been also termed receptor mosaics [135-139]. Keeping these facts in mind, the reader of this review was already introduced to the concept of fractal analysis of ligand-receptor interactions [13]. These ideas have been already included in modern models that look at ligand binding in the "age of dimers" as we should acknowledge [140,141]. Further steps in these models are the evaluation of dimer symmetry [142] as well as the structural form of these receptor mosaics which is important for signaling, trafficking, and oligomer intercommunication [143]. Besides these GPCR models, structural genomics have been used for protein expression, purification, and crystallography [144]. 
In the field of SSTR, the year 2000 marked the starting point for new knowledge regarding dimer formation. Rocheville et al. described the formation of functional homo- and hetero-dimers [145]. This experiment unveiled novel biochemical properties of the ligandreceptor interaction in the sense of molecular cross-talk among the receptor subtypes. Hukovic et al. have shown an agonist-dependent regulation of cloned human SSTR1 [146]. In vivo studies have shown a positive effect of pre-exposure of SST on the expression of its own subtype 2 receptors in the arcuate nucleus [147]. In the following years, more information has been gathered. Differences in the dimerization of SSTR subtypes have been investigated by the research groups of Pfeiffer, Grant, and Jacobs [148-150]. These studies revealed differences in receptor kinetics depending on the type of dimers. Durán-Prado and collaborators have recently summarized data on heterodimer formation in relation to SST signaling and control [151]. Besides the situation of dimerization induced by an agonist, Reubi et al. have recently described the effect of a DOTA chelator that changes the action profile of the tracer, i.e., from antagonist to agonist [152].

While we are accustomed to think exclusively one way on SST and SSTR while looking at SSTR imaging, reallife biochemistry might be different. Besides the property of SSTR dimer formation, heterodimers involving other receptors types are now known or have been developed experimentally. One type of heterodimer is related to dopamine and SSTR which was originally described by Rocheville [153]. These hetero-oligomers of dopamine and SSTR had enhanced functional activity. The second type of heterodimer includes opioid and SSTR, which were originally described by Pfeiffer et al. [154,155]. In this context, it is important to mention other work done on opioid receptors. Using an in vitro system Gomes et al. [156] have observed that rather low doses of some delta-selective ligands can lead to a significant increase in the binding of a mu receptor agonist. It is important to keep in mind these heterologous interactions since patients with NET might be treated at some time with these types of pharmacological agents. Analysis of the GPRC genome shows interesting relationships of the SST and opioid receptors [157]. The MCHR2 and NPBWR2 genes are found at the roots of the SST and opioid receptors branch. GPR32 and GPR33 are under the SST and opioid receptor cluster. Among opioid receptors heterodimers of $\mathrm{mu}$ and delta receptors can be found [156]. A physiological meaning of this type of heterodimers might be related to nociception.

New data on receptor functioning requires also a new language. Taking an example of receptor dimerization in relation to SST [153] Kenakin [158] describes new interactions on the SSTR5-D2 heterodimer, termed conduit, having SST 14 as a ligand, termed guest. The dopamine receptor D2 agonist quinpirole increases the binding affinity of somatostatin-14 while the dopamine receptor D2 antagonist sulpiride decreases the binding. These last two are called modulators. O'Toole et al. have described the co expression of SSTR2 and D2 receptors in GEP tumors [159]. The authors concluded that bispecific agonists such as SST(2)/SST(5) or SST(2)/D(2) could be tested in these tumors. This type of reasoning has stimulated research work on the side of the ligands leading to the synthesis of ligands such as BIM23A357 and BIM23A770 which can bind both SST and dopamine receptors [160]. Recently, Arvigo et al. [161] have described somatostatin and dopamine receptor interactions in cell lines (prostate and lung cancer). Synergistic stimulation had effects on the inhibition of cell proliferation.

Following ligand binding on the cell membrane, further mechanisms have to control the signaling of the ligands. One of these mechanisms involves arrestins. Receptors can be classified according to their ability to bind arrestin [162]: “Class A receptors ( $\$ 2$ adrenergic receptor, $\mathrm{mu}$ opioid receptor, endothelin type A receptor, dopamine D1A receptor, and $\alpha 1 \mathrm{~b}$ adrenergic receptor) can bind $\beta$-arrestin 2 with higher affinity than $\beta$ arrestin 1 and do not interact with visual arrestin. In contrast, class B receptors (angiotensin II type 1A receptor, neurotensin receptor 1, vasopressin V2 receptor, thyrotropin-releasing hormone receptor, and substance $P$ receptor) bound both $ß$ arrestin isoforms with similar high affinities and also interacted with visual arrestin" [162]. The arrestins, $ß-1$ and $ß-2$, are negative regulators of GPCR signaling which translocate to the cell membrane. Here, they bind the occupied receptors. This is followed by uncoupling of the receptors from G-proteins, leading finally to internalization, and by this, desensitation occurs [163]. Further actions of arrestin on histone acetylation and gene transcription have been described [164]. In a similar way as it happens with GPCR, the arrestins can also dimerize [165]. SSTR regulation by arrestins has also been demonstrated in recent years [166-168]. Finally the so-called RAMPS function as accessory proteins that are needed for the adequate placing and function of certain GPCRs [169].

\section{GPCR, caveolae, lipid rafts, and oxidative stress}

The cellular localization of the receptors implies that they have to interact with the membrane and this is a function that depends on its physical properties. I will mention few structures that are relevant in this context. The caveolae membrane system describes a functional complex related to the delivery of molecules to specific locations in the cell [170]. Subunits of G proteins can bind to caveolae so that their function is also related to these elements [171-173]. Finally, the structure of a 
receptor is connected to cholesterol [174-176]. A reduction of cholesterol can lead to an increase in ligand binding, however, the level of intracellular signaling might be reduced [177]. Not only cholesterol (and maybe cholesterol modifying therapies) but also micronutrients can play a role on membrane fluidity [178]. Membrane rigidity depends also on lipid peroxidation [179]. Receptor density and membrane fluidity can be influenced by oxidative stress [180,181]. While oxidative stress can be sought within the diseased organ, one should also consider potential side effects of medical actions. We have recently described the negative influence of radiation exposure during peptide receptor radionuclide therapy on Se levels [182]. By decreasing Se levels, several protective selenoproteins will be compromised resulting in impaired protection against oxidative stress [183]. It follows that nutrition, anti-oxidants, and lipid-modifying therapies have to be included in our vision of receptor function [184] and possibly modulation. Among the caveolins [185], Caveolin-1 is currently being investigated in the context of tumor development [186]. Regulating mechanisms that maintain its expression could turn to be a potential tumor regulator due to tumor suppressor functions.

\section{The total environment in the light of PET/CT imaging- images and postulates}

When we carry out SSTR imaging for NET diagnosis, we are conditioned a priori to consider octreotide uptake as tumor expression. We should realize that SST is only one player among others in a complex system [187-192]. When we do SSTR imaging, we have to realize that modern imaging techniques have the potential of delivering new evidence on the distribution of SSTR. Based on the use of modern PET/CT imaging with a $\mathrm{Ga}^{68}$-labeled octreotide tracer, it is now possible to detect tracer uptake in bodily structures that have not been considered before. Figure 1 presents the uptake of 99mTc-labeled HYNIC-TOC in a fibrotic abdominal surgical scar, showing that tissue repair involves SSTR. An "ignored" finding in NET patients can be seen in Figure 2 where tracer uptake within a small intestinal loop is demonstrated. On theoretical grounds, one can suspect that an inflammatory process is present. Inflammatory gut diseases and NET have been discussed above.

Figures 3 and 4 depict octreotide localized uptake in peri-muscular structures of the thigh both in a male and a female patient. The images have been taken from PET/CT studies of patients with NET investigated with 68Ga-DOTA-TOC. The distribution pattern delineates muscular fasciae [193]. For a general description of the distribution of superficial and deep fasciae of the body, the readers are referred to Gerlach [194]. Such fascia structures have a longitudinal distribution between the

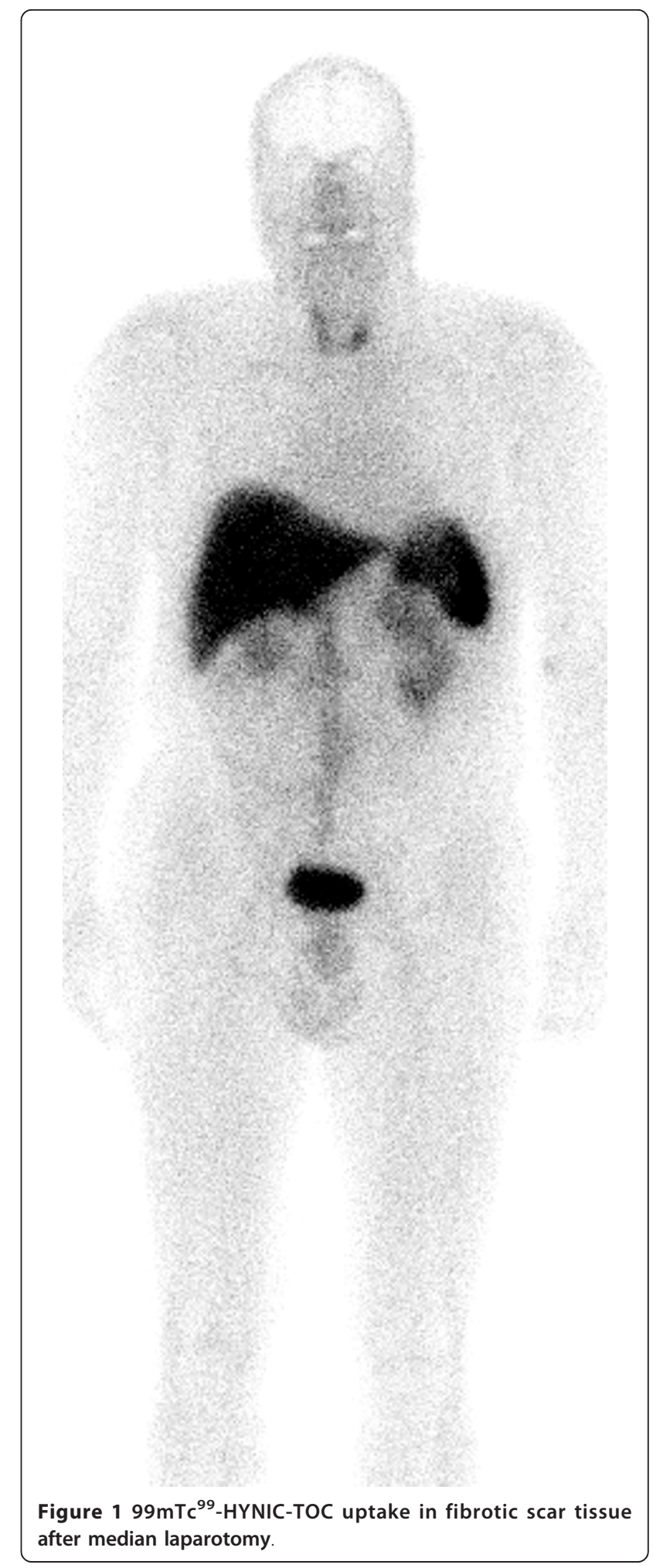

muscles and are considered to be involved in epimuscular myofascial force transmission (e.g., Figure nine in [195]). Conventional three-view reconstruction algorithms in Nuclear Medicine do not produce a suitable 


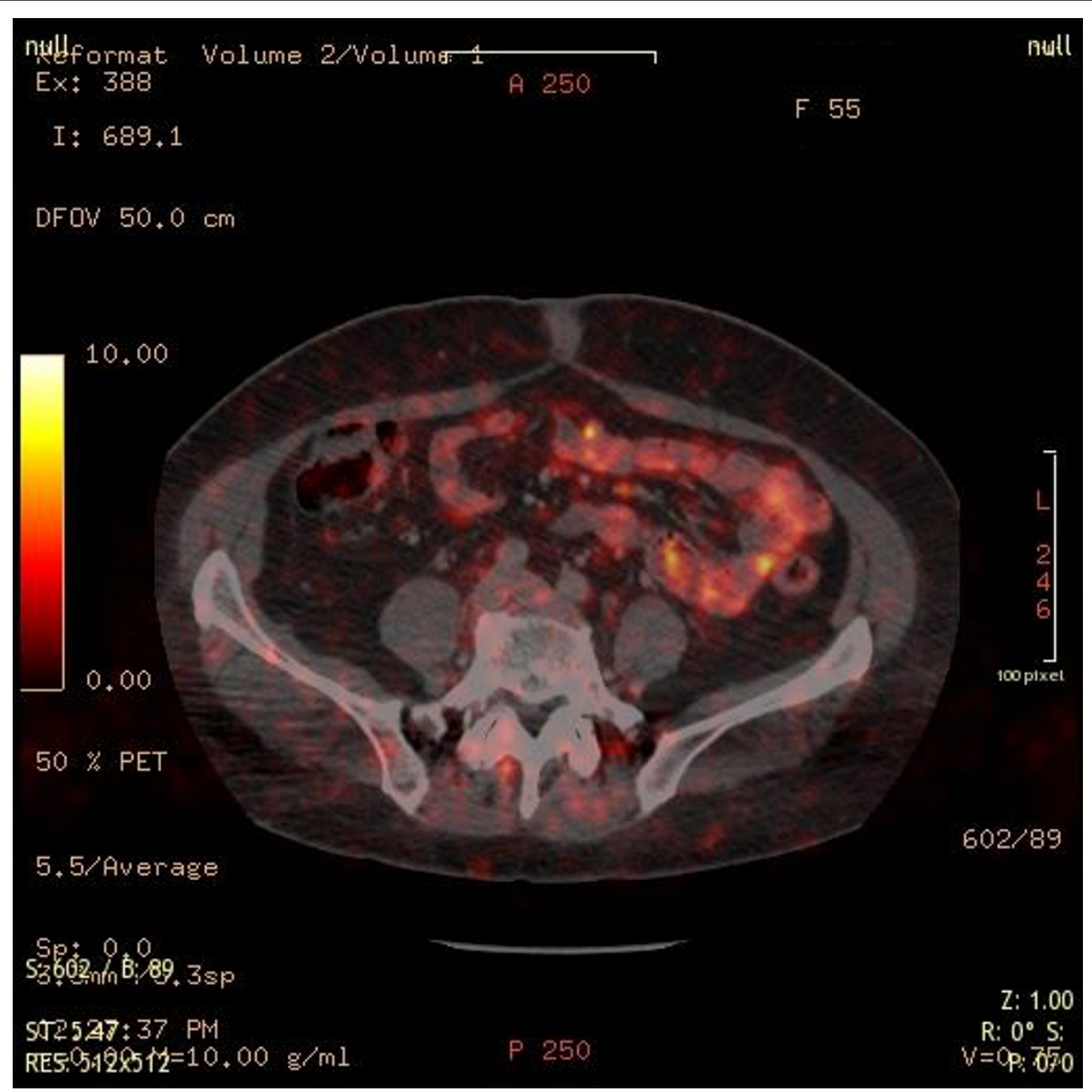

Figure $2 \mathrm{PET} / \mathrm{CT} \mathrm{Ga}{ }^{68}$-TOC uptake in intestinal structures, in abdominal muscles, and abdominal fatty tissue. The image was taken from a 56 -year-old female patient with a NET.

image of this type of aligned structures. An adequate approach to achieve this would be to apply the principles of diffusion spectrum MRI tractography [196]. The applicability of this method in the investigation of myocardial, i.e., muscular structures, has been recently demonstrated [197,198].

Between the fasciae and connective tissue in the body, tensile forces are active. Standerwick and Roberts have described these relations for craniofacial growth [199]. I propose that the punctual uptake is in relation to mechanosensing, since distension of the muscles, e.g., through eccentric exercise, will act on these structures [200-202]. This is the basic assumption that we have included in the musculoskeletal model of thyroid-associated orbitopathy [76].

The careful observer of figures will also recognize tracer uptake in the subcutaneous fatty structures. While it is not possible to deliver an exact anatomical correlate of this binding site, the distribution pattern might be involved in processes of metabolic signaling such as lipolysis $[203,204]$. In humans, changes of both SST secretion and SSTR expression has been described in conditions of infection and inflammation of adipose tissue [205].

Recent data on SSTR in the early years of the new century In the process of editing the final version of this manuscript, I came across some recent data on SSTR which should be mentioned here. The data presented above has in a way a historical character. New developments, however, change the face of science.

One of the most relevant aspects on SSTR is that of truncated somatostatin receptors. The group of Córdoba-Chacón et al. have described a series of new splicing variants of the SSTR-5 molecule in pituitary tumors as well as in rodents [206,207]. The result of these alterations is the appearance of SSTR that have different numbers of trans-membrane domains (TMD). In their recent publication [208], they describe some characteristics of the human spliced variants of the SST receptor subtype 5. Among these is the novel evidence that demonstrate that an SST can react in different ways to very similar analogs of SST. One clinically important 


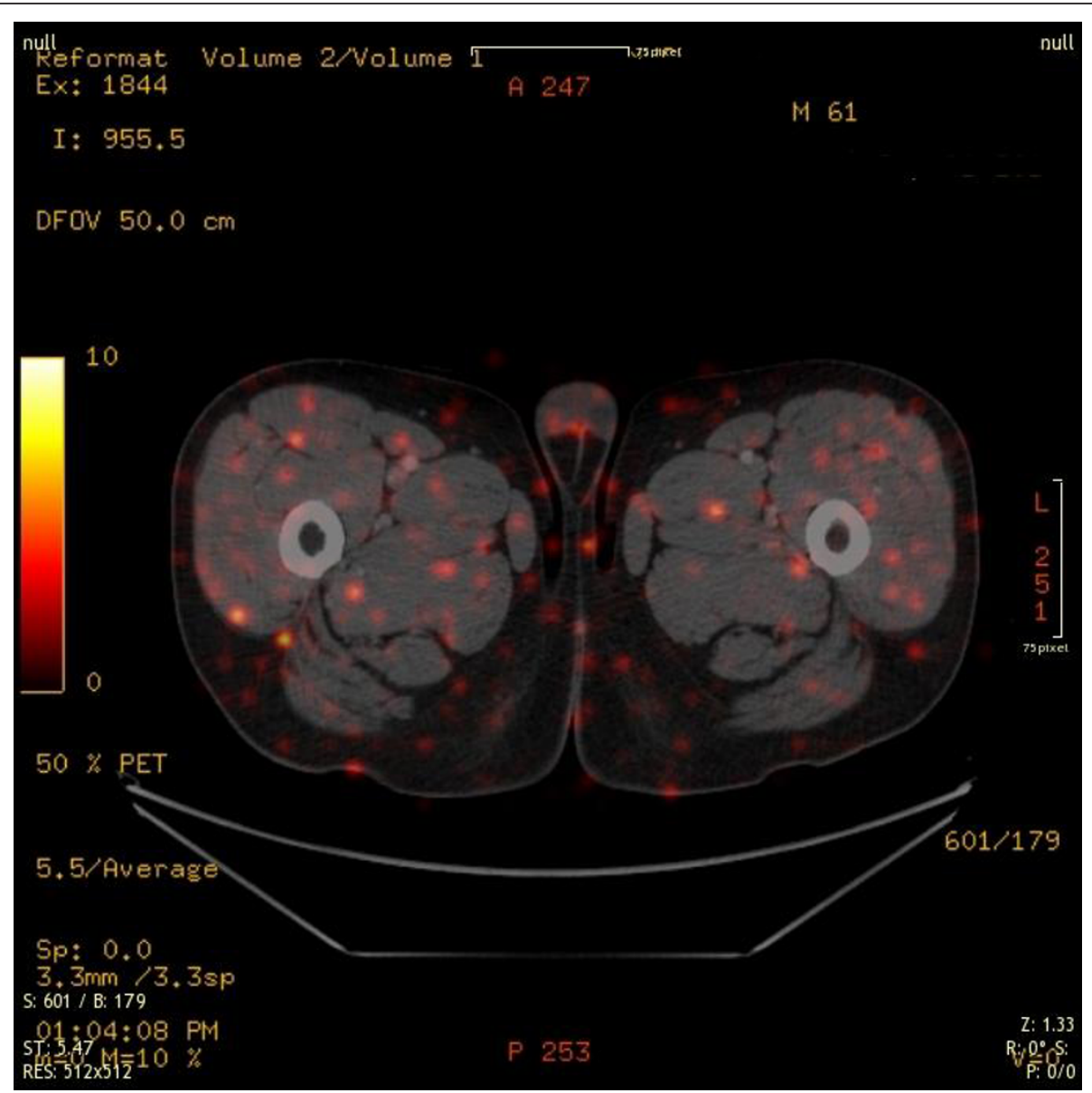

Figure 3 A 61-year-old male patient presenting intense uptake in muscular structures and in fatty tissues. Low levels of Se were documented in this case.

issue is the finding of SST analog-resistant somatotropinomas where the variant called hsst5TMD4 was found [209]. In their review on the topic of truncated somatostatin receptors, Córdoba-Chacón et al. discuss the issues that led to a novel reasoning for the interpretation of SST-knockout models [208]. The data discussed originated new explanations for the different effects of SST and cortistatin at different levels. This finding is of outmost importance in the clinical management of patients with NET, since sole tracer binding will not be able to identify the existence of this truncated receptor variant, while at the same time therapeutic efforts with either unlabelled or labeled SSTA might remain unsuccessful. Implementation of these methods in cases of NET is badly needed!

Besides changes in the receptor peptide structure, a further factor that influences binding is the carbohydrate component of the moiety [210]. In a recent article, Møller et al. discuss the influence of the carbohydrate component on SSTR (section 2.3.2. in [211]). Glycosylation moieties are present in SSTR5 [212].
An ample description and discussion on somatostatin receptors based on the experience with patients with acromegaly has been recently presented by Colao et al. [213]. The clear advantage in the field of acromegaly it that it is possible to investigate the efficacy of different therapeutic approaches by determining the targets, e.g., growth hormone, IGF-I, as well as the characteristics of the pituitary tumor. This is not always the case in cases with NET since the decision to initiate treatment might simply come from scintigraphic results [214] even when the patients have no significant endocrinological alterations. One important aspect in Colao's paper is the description of SSA resistant cases. This situation might also occur in NET.

Man is not alone in nature. Developmental aspects of receptors have been presented by other authors. Gahete et al. have summarized data related to the development of somatostatin receptors from fish to mammals [215]. Emphasis has been put on the section on new SST receptors. In a similar way Vaudry et al. have described the evolution of urotensin receptors [216]. These early 


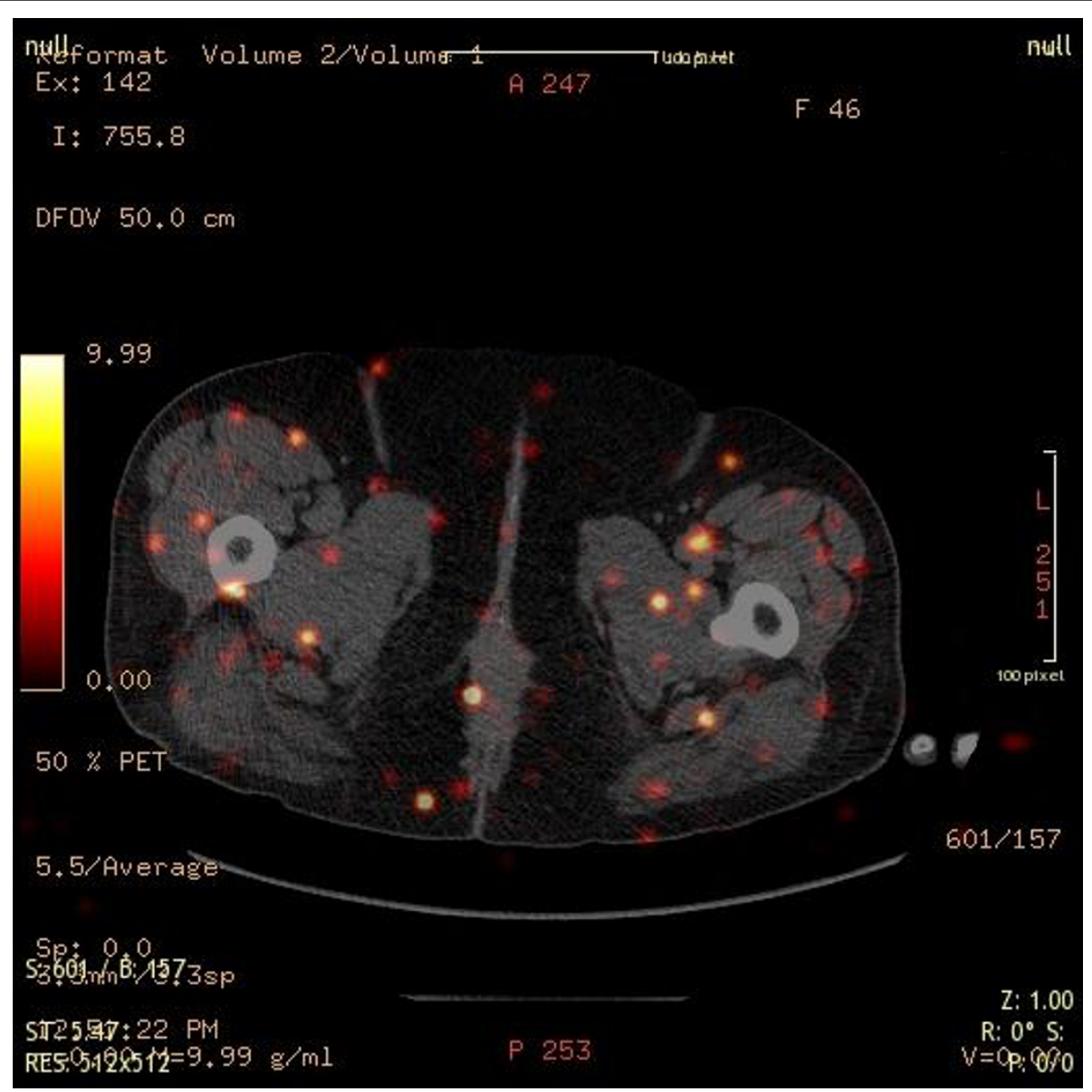

Figure 4 A 46-year-old female patient with axial mis-alignment, the mid-line is shifted to the left. The uptake intensity is greater as in the previous case. Axial mis-alignment could influence mechanotension of the muscular structures and produce enhanced SSTR expression.

forms of SSTRs have the potential of being more easily accessed for scientific research.

\section{Conclusions: the fiction in science $[217,218]$}

Science is an art. In doing medical research, we attempt to recognize the elements involved in this art frame and await confirmation of hypotheses by going through empirical and evidence-based paths [219-226]. In view of the biochemical complexity of receptor interaction outlined in this review, I believe that the most suitable graphical and operational representation is that of coalition chess as proposed by Arnold Schoenberg in the 1920s [227]. Coalition chess involves four players with each player moving different chess figures. It allows the possibility to form coalitions between the players-as agonists or antagonists. Using this chess variant as a concept, one can imagine "the players" being involved in receptor interaction. Modern methods like functional proteomics and genomics [228], functional nutrigenomics [229], receptorome mining [98], chemogenomics [230], and metabolomics [231] will surely gain relevance in the field of Nuclear Medicine in order to decipher these multiple interactions. Multiagent multitarget procedures, similar to the herbal combination described herein, could be analyzed by nutriome methods [232]. For NM, one could envision the use of multivalent tracers or tracer mixtures in therapeutic situations. In addition, we can expect that a new terminology will be proposed for receptor forms and interactions [233,234]. The influence of morphogens and morphostats on NET is also added as a research direction to be kept in mind [190,191,235-240]. Finally, basic research will start to get involved with spliceosome dynamics [241] in order to provide answers to the truncated forms of SSTR.

I present a graphical summary of this review in Figure 5. Upon seeing the figure, the reader might recall the words of William Wordsworth: "My heart leaps up when I behold a rainbow in the sky". I propose that when we look at octreotide scintigraphy, while still strictly sticking to the procedure guidelines [242,243], we should think on inflammation, nociception, mechanosensing, chemosensing, fibrosis, taste, vascularity, and also tumor. An increase of any of these single processes 


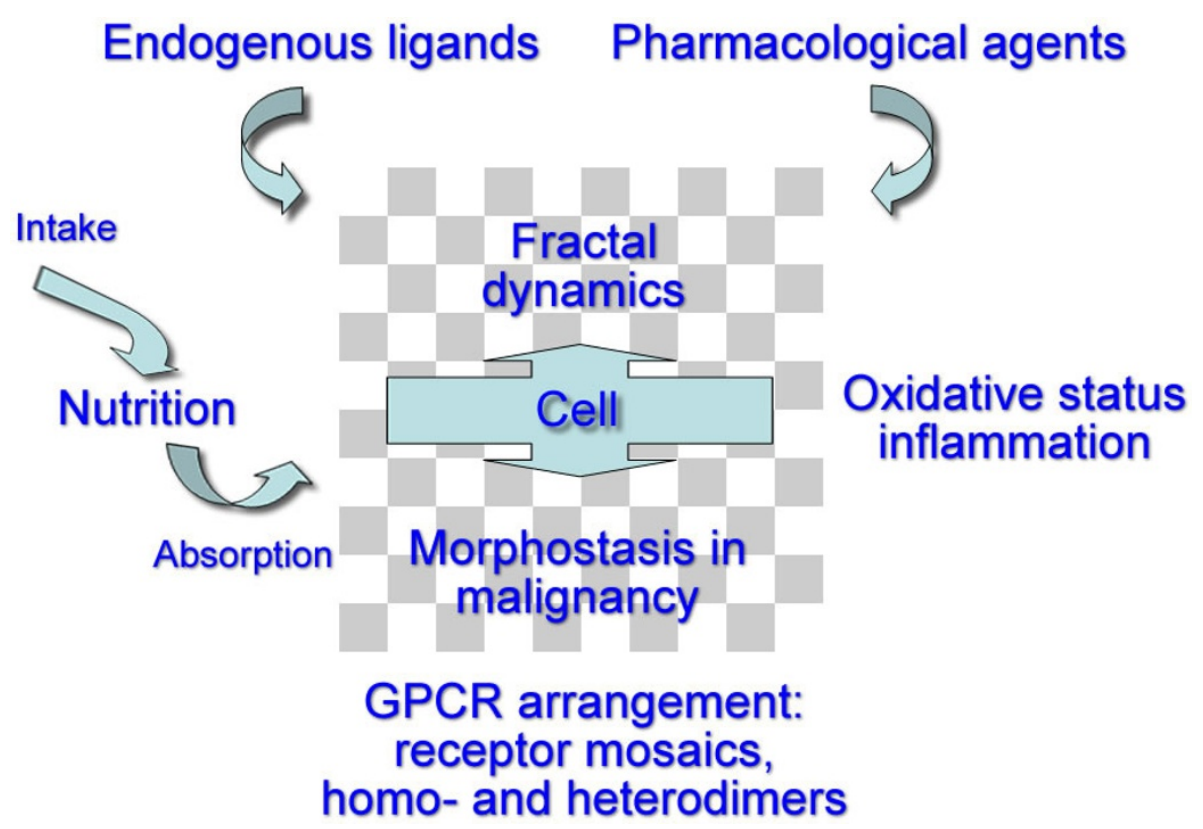

Figure $\mathbf{5}$ Graphical summary of this review. This graphical summary of this review presents several real-time players that make up the total environment behind octreotide scintigraphy. (1) Nutrition: sufficient macro- and micronutrients of good quality are the starting point. Intestinal function will have an influence on absorption. (2) Endogenous ligands: somatostatin, corticostatin, urotensin, neuronostatin. (3) Pharmacological agents: octreotide, DOTA-chelators in tracers, lanreotide, omeprazole, lipid modifiers. (4) Ability to cope with oxidative status and inflammatory conditions. (5) Characteristics of the GPCR system: homo- and heterodimers, truncated receptors, RAMPS, arrestins, etc. (6) Morphostats, and cell regulators in malignancy.

might result in increased tracer uptake making up a rainbow in our imaging sky. While people tend to believe what they see, and Nuclear Medicine is an imaging specialty indeed, we should not forget the basic principle of uncertainty in science [244]. Quoting Castillo while he refers to Feynman [245] one reads: "He goes on to say that if we are free of doubt and ignorance, we will not get any new ideas and make no progress".

\section{Author information}

Roy Moncayo is trained in Internal Medicine, Endocrinology, Nuclear Medicine, Chinese Acupunture, and Western Herbal Therapies and holds a MAS in Health and Fitness. He is Deputy Head of the Department of Nuclear Medicine at the Medical University in Innsbruck. His clinical experience with octreotide is centered on thyroid-associated orbitopathy. He carries out complementary work on musculoskeletal disorders at WOMED, Innsbruck.

\section{Abbreviations}

68Ga-TOC: ${ }^{68} \mathrm{Ga} a-D O T A^{0}-$ Tyr $^{3}$ octreotide; 7TM: seven7 -transmembrane helical receptors; CNS: central nervous system; Gl: gastrointestinal; GPCR: G-protein coupled receptors; MRI: magnetic resonance imaging; NET: neuroendocrine tumors; RAMPS: receptor-activity-modifying proteins; Se: selenium; SSA: somatostatin analogs; SST: somatostatin; SSTR: somatostatin receptors; TAO: thyroid- associated orbitopathy; TCM: traditional Chinese medicine; TMD: transmembrane domains.

\section{Acknowledgements}

The Nuclear Medicine images have been produced at the Department of Nuclear Medicine of the Medical University of Innsbruck. Financial support for literature search and ordering was provided by WOMED.

The first version of this paper was presented at the: "3rd INTERNATIONAL CONFERENCE ON RADIOPHARMACEUTICAL THERAPY (ICRT-2009)" in Cartagena, Colombia, on November 2009. The article was originally conceived as an editorial but come time come a larger scope.

The author wants to express sincere thanks to the reviewers who made several precious and constructive suggestions.

\section{Author details}

'Department of Nuclear Medicine, Medical University of Innsbruck, Innsbruck, Austria ${ }^{2}$ WOMED, Karl-Kapferer-Strasse 5, 6020 Innsbruck, Austria

\section{Authors' contributions}

RM conceived the idea, wrote the manuscript, and drew the graphics.

Competing interests

The author declares that he has no competing interests.

Received: 10 May 2011 Accepted: 26 July 2011 Published: 26 July 2011

\section{References}

1. Rolleman EJ, Kooij PP, De Herder WW, Valkema R, Krenning EP, de Jong M: Somatostatin receptor subtype 2-mediated uptake of radiolabelled somatostatin analogues in the human kidney. Eur I Nucl Med Mol Imaging 2007, 34:1854-1860.

2. Hofland LJ, Lamberts SW, van Hagen PM, Reubi JC, Schaeffer J, Waaiiers M, et al: Crucial role for somatostatin receptor subtype 2 in determining the uptake of [111ln-DTPA-D-Phe1]octreotide in somatostatin receptorpositive organs. J Nucl Med 2003, 44:1315-1321. 
3. Mansi $L$, Virgolini I: Diagnosis and therapy are walking together on radiopeptides' avenue. Eur J Nucl Med Mol Imaging 2011, 38:605-612.

4. Henri V: Lois générales de l'action des diastases. Paris , 11903.

5. Langley JN: On the reaction of cells and of nerve-endings to certain poisons, chiefly as regards the reaction of striated muscle to nicotine and to curare. J Physiol 1905, 33:374-413.

6. Michaelis L, Menten M: Die Kinetik der Invertinwirkung. Biochem Z 1913, 49:333-369.

7. Clark AJ: The reaction between acetyl choline and muscle cells. J Physio 1926, 61:530-546.

8. Stephenson RP: A modification of receptor theory. Br J Pharmacol Chemother 1956, 11:379-393.

9. Thron CD: On the analysis of pharmacological experiments in terms of an allosteric receptor model. Mol Pharmacol 1973, 9:1-9.

10. Kilbourn MR, Zalutsky MR: Research and clinical potential of receptor based radiopharmaceuticals. J Nucl Med 1985, 26:655-662.

11. Savageau MA: Michaelis-Menten mechanism reconsidered: implications of fractal kinetics. J Theor Biol 1995, 176:115-124.

12. Grima $R$, Schnell $S$ : A systematic investigation of the rate laws valid in intracellular environments. Biophys Chem 2006, 124:1-10.

13. Aranda JS, Salgado E, Muñoz-Diosdado A: Multifractality in intracellular enzymatic reactions. J Theor Biol 2006, 240:209-217.

14. Guillemin R: Hypothalamic hormones a.k.a. hypothalamic releasing factors. J Endocrinol 2005, 184:11-28.

15. Guillemin R: Somatostatin: The beginnings, 1972. Mol Cell Endocrinol 2008, 286:3-4

16. Brazeau $P$, Vale $W$, Burgus $R$, Ling $N$, Butcher $M$, Rivier J, et al: Hypothalamic polypeptide that inhibits the secretion of immunoreactive pituitary growth hormone. Science 1973, 179:77-79.

17. Marbach P, Bauer W, Briner U, Dopfner W, Petcher T, Pless J: Structurefunction relationships of somatostatin analogs. Horm Res 1988, 29:54-58.

18. Pless J: The history of somatostatin analogs. J Endocrinol Invest 2005, 28:1-4.

19. Weckbecker G, Lewis I, Albert R, Schmid HA, Hoyer D, Bruns C: Opportunities in somatostatin research: biological, chemical and therapeutic aspects. Nat Rev Drug Discov 2003, 2:999-1017.

20. Porstad OP, Schonbrunn A, Martin JB: Somatostatin radioreceptor assay: development and application to the measurement of somatostatinlike activity in the rat central nervous system. Can J Biochem Cell Biol 1983, 61:532-537.

21. Weckbecker G, Raulf F, Stolz B, Bruns C: Somatostatin analogs for diagnosis and treatment of cancer. Pharmacol Ther 1993, 60:245-264

22. Bakker WH, Krenning EP, Breeman WA, Koper JW, Kooij PP, Reubi JC, et al: Receptor scintigraphy with a radioiodinated somatostatin analogue: radiolabeling, purification, biologic activity, and in vivo application in animals. J Nucl Med 1990, 31:1501-1509.

23. Krenning EP, Bakker WH, Kooij PP, Breeman WA, Oei HY, de Jong M, et al: Somatostatin receptor scintigraphy with indium-111-DTPA-D-Phe-1octreotide in man: metabolism, dosimetry and comparison with iodine123-Tyr-3-octreotide. J Nucl Med 1992, 33:652-658.

24. Gabriel M, Muehllechner P, Decristoforo C, von Guggenberg E, Kendler D, Prommegger R, et al: 99mTc-EDDA/HYNIC-Tyr(3)-octreotide for staging and follow-up of patients with neuroendocrine gastro-entero-pancreatic tumors. Q J Nucl Med Mol Imaging 2005, 49:237-244.

25. Hofland L, Lamberts SW: The pathophysiological consequences of somatostatin receptor internalization and resistance. Endocr Rev 2003, 24:28-47.

26. Deshmukh MV, Voll G, Kühlewein A, Mäcke H, Schmitt J, Kessler H, et al: NMR studies reveal structural differences between the gallium and yttrium complexes of DOTA-D-Phe1-Tyr3-octreotide. J Med Chem 2005, 48:1506-1514

27. Longnecker DS, Lilja HS, French J, Kuhlmann E, Noll W: Transplantation of azaserine-induced carcinomas of pancreas in rats. Cancer Lett 1979, 7:197-202.

28. Melis M, Forrer F, Capello A, Bijster M, Bernard BF, Reubi JC, et al: Upregulation of somatostatin receptor density on rat CA20948 tumors escaped from low dose [177Lu-DOTA0,Tyr3] octreotate therapy. Q J NuCl Med Mol Imaging 2007, 51:324-333.

29. Gabriel M, Decristoforo C, Kendler D, Dobrozemsky G, Heute D, Uprimny C, et al: 68Ga-DOTA-Tyr3-octreotide PET in neuroendocrine tumors: comparison with somatostatin receptor scintigraphy and CT. J NuCl Med 2007, 48:508-518.

30. Modlin IM, Shapiro MD, Kidd M: Carcinoid tumors and fibrosis: an association with no explanation. Am J Gastroenterol 2004, 99:2466-2478.

31. Druce $M$, Rockall $A$, Grossman AB: Fibrosis and carcinoid syndrome: from causation to future therapy. Nat Rev Endocrinol 2009, 5:276-283.

32. Pan Q, Li DG, Lu HM, Lu LY, You HN, Xu QF: Relationship between somatostatin receptors and activation of hepatic stellate cells. Chin Med $J$ (Engl) 2004, 117:1665-1669.

33. Öhrvall U, Westlin JE, Nilsson S, Wilander E, Juhlin C, Rastad J, et al: Human biodistribution of [111/n]diethylenetriaminepentaacetic acid-(DTPA)-D[Phe1]-octreotide and peroperative detection of endocrine tumors. Cancer Res 1995, 55:5794s-5800s.

34. Lebtahi R, Moreau S, Marchand-Adam S, Debray MP, Brauner M, Soler P, et al: Increased uptake of $111 \mathrm{In}$-octreotide in idiopathic pulmonary fibrosis. J Nucl Med 2006, 47:1281-1287.

35. Chen CC, Czerwiec FS, Feuillan PP: Visualization of fibrous dysplasia during somatostatin receptor scintigraphy. J Nucl Med 1998, 39:238-240.

36. Fjallskog ML, Ludvigsen E, Stridsberg M, Oberg K, Eriksson B, Janson ET: Expression of somatostatin receptor subtypes 1 to 5 in tumor tissue and intratumoral vessels in malignant endocrine pancreatic tumors. Med Oncol 2003, 20:59-67.

37. Danesi R, Agen C, Benelli U, Paolo AD, Nardini D, Bocci G, et al: Inhibition of experimental angiogenesis by the somatostatin analogue octreotide acetate (SMS 201-995). Clin Cancer Res 1997, 3:265-272.

38. Woltering EA, Barrie R, O'dorisio TM, Arce D, Ure T, Cramer A, et al: Somatostatin analogues inhibit angiogenesis in the chick chorioallantoic membrane. J Surg Res 1991, 50:245-251.

39. Guo MM, Tan QH, Fan H, Huang MH, Wang CH, Qiu XQ, et al: [Changes of somatostatin and expression of somatostatin receptor in small intestine and liver tissues during macaque development]. Acta Physio/ Sin 2005, 57:719-724.

40. Rong W, Winchester WJ, Grundy D: Spontaneous hypersensitivity in mesenteric afferent nerves of mice deficient in the sst2 subtype of somatostatin receptor. J Physiol 2007, 581:779-786.

41. Hens J, Vanderwinden JM, De Laet MH, Scheuermann DW, Timmermans JP. Morphological and neurochemical identification of enteric neurones with mucosal projections in the human small intestine. J Neurochem 2001, 76:464-471.

42. Roca B, Fernandez-Valencia R, Arilla E: Effects of fasting and refeeding on somatostatin concentration and binding to cytosol from rabbit gastric mucosa. Gut 1988, 29:642-646.

43. Gonkowski S, Calka J: Changes in the somatostatin (SOM)-like immunoreactivity within nervous structures of the porcine descending colon under various pathological factors. Exp Mol Pathol 2010, 88:416-423.

44. Koch TR, Carney JA, Morris VA, Go VL: Somatostatin in the idiopathic inflammatory bowel diseases. Dis Colon Rectum 1988, 31:198-203.

45. Rong W, Winchester WJ, Grundy D: Spontaneous hypersensitivity in mesenteric afferent nerves of mice deficient in the sst2 subtype of somatostatin receptor. J Physiol 2007, 581:779-786.

46. Reubi JC, Laissue J, Waser B, Horisberger U, Schaer JC: Expression of somatostatin receptors in normal, inflamed, and neoplastic human gastrointestinal tissues. Ann N Y Acad Sci 1994, 733:122-137.

47. West NE, Wise PE, Herline AJ, Muldoon RL, Chopp W, Schwartz DA: Carcinoid tumors are 15 times more common in patients with Crohn's disease. Inflamm Bowel Dis 2007, 13:1129-1134.

48. Grassia R, Bodini P, Dizioli P, Staiano T, liritano E, Bianchi $G$, et al: Neuroendocrine carcinomas arising in ulcerative colitis: coincidences or possible correlations? World J Gastroenterol 2009, 15:4193-4195.

49. Sciola V, Massironi S, Conte D, Caprioli F, Ferrero S, Ciafardini C, et al: Plasma chromogranin a in patients with inflammatory bowel disease. Inflamm Bowel Dis 2009, 15:867-871.

50. Genton L, Kudsk KA: Interactions between the enteric nervous system and the immune system: role of neuropeptides and nutrition. Am J Surg 2003, 186:253-258

51. Van Op dB, van Nassauw L, Lantermann $K$, van Marck E, Timmermans JP: Effect of intestinal inflammation on the cell-specific expression of somatostatin receptor subtypes in the murine ileum. Neurogastroenterol Motil 2007, 19:596-606 
52. Van $\mathrm{Op} \mathrm{dB}$, Lantermann $K$, Torfs $P$, van Marck E, van Nassauw L, Timmermans JP: Distribution and expression levels of somatostatin and somatostatin receptors in the ileum of normal and acutely Schistosoma mansoni-infected SSTR2 knockout/lacZ knockin mice. Neurogastroenterol Motil 2008, 20:798-807.

53. Corleto VD: Somatostatin and the gastrointestinal tract. Curr Opin Endocrinol Diabetes Obes 2010, 17:63-68.

54. Mantyh PW, Hunt SP: Neuropeptides are present in projection neurones at all levels in visceral and taste pathways: from periphery to sensory cortex. Brain Res 1984, 299:297-312.

55. Tal M, Ammar DA, Karpuj M, Krizhanovsky V, Naim M, Thompson DA: A novel putative neuropeptide receptor expressed in neural tissue, including sensory epithelia. Biochem Biophys Res Commun 1995, 209:752-759.

56. Carlton SM, Du J, Zhou S, Coggeshall RE: Tonic control of peripheral cutaneous nociceptors by somatostatin receptors. J Neurosci 2001, 21:4042-4049.

57. Carlton SM, Zhou S, Kraemer B, Coggeshall RE: A role for peripheral somatostatin receptors in counter-irritation-induced analgesia. Neuroscience 2003, 120:499-508.

58. Bär KJ, Schurigt U, Scholze A, Segond von Banchet G, Stopfel N, Bräuer R, et al: The expression and localization of somatostatin receptors in dorsal root ganglion neurons of normal and monoarthritic rats. Neuroscience 2004, 127:197-206.

59. Abd El-Aleem SA, Morales-Aza BM, McQueen DS, Donaldson LF: Inflammation alters somatostatin mRNA expression in sensory neurons in the rat. Eur J Neurosci 2005, 21:135-141.

60. Dong ZQ, Xie H, Ma F, Li WM, Wang YQ, Wu GC: Effects of electroacupuncture on expression of somatostatin and preprosomatostatin mRNA in dorsal root ganglions and spinal dorsal horn in neuropathic pain rats. Neurosci Lett 2005, 385:189-194.

61. Pintér $E$, Helyes Z, Szolcsányi J: Inhibitory effect of somatostatin on inflammation and nociception. Pharmacol Ther 2006, 112:440-456.

62. Rong W, Winchester WJ, Grundy D: Spontaneous hypersensitivity in mesenteric afferent nerves of mice deficient in the sst2 subtype of somatostatin receptor. J Physiol 2007, 581:779-786.

63. Pan HL, Wu ZZ, Zhou HY, Chen SR, Zhang HM, Li DP: Modulation of pain transmission by G-protein-coupled receptors. Pharmacol Ther 2008, 117:141-161.

64. Carlton SM, Zhou S, Du J, Hargett GL, Ji G, Coggeshall RE: Somatostatin modulates the transient receptor potential vanilloid 1 (TRPV1) ion channel. Pain 2004, 110:616-627.

65. Gillespie PG, Walker RG: Molecular basis of mechanosensory transduction. Nature 2001, 413:194-202.

66. Huang $\mathrm{CL}$ : The transient receptor potential superfamily of ion channels. $J$ Am Soc Nephrol 2004, 15:1690-1699.

67. O'Neil RG, Heller S: The mechanosensitive nature of TRPV channels. Pflugers Arch 2005, 451:193-203.

68. Liedtke W: Transient receptor potential vanilloid channels functioning in transduction of osmotic stimuli. J Endocrinol 2006, 191:515-523.

69. Endres-Becker J, Heppenstall PA, Mousa SA, Labuz D, Oksche A, Schäfer M, et al: Mu-opioid receptor activation modulates transient receptor potential vanilloid 1 (TRPV1) currents in sensory neurons in a model of inflammatory pain. Mol Pharmacol 2007, 71:12-18.

70. Mudie AS, Holland GR: Local opioids in the inflamed dental pulp. J Endod 2006, 32:319-323.

71. Lamberts SW, Bakker WH, Reubi JC, Krenning EP: Somatostatin-receptor imaging in the localization of endocrine tumors. N Engl J Med 1990, 323:1246-1249.

72. Eschalier A, Aumaître O, Ardid D, Fialip J, Duchêne-Marullaz P: Long-lasting antinociceptive effect of RC-160, a somatostatin analog, in mice and rats. Eur J Pharmacol 1991, 199:119-121.

73. Betoin F, Ardid D, Herbet A, Aumaitre O, Kemeny JL, Duchene-Marullaz P, et al: Evidence for a central long-lasting antinociceptive effect of vapreotide, an analog of somatostatin, involving an opioidergic mechanism. J Pharmacol Exp Ther 1994, 269:7-14.

74. Moncayo R, Baldissera I, Decristoforo C, Kendler D, Donnemiller E: Evaluation of immunological mechanisms mediating thyroid-associated ophthalmopathy by radionuclide imaging using the somatostatin analog 111 In-octreotide. Thyroid 1997, 7:21-29.
75. Kainz H, Bale R, Donnemiller E, Gabriel M, Kovacs P, Decristoforo C, et al: Image fusion analysis of (99 m)Tc-HYNIC-octreotide scintigraphy and CT/ MRI in patients with thyroid-associated orbitopathy: the importance of the lacrimal gland. Eur J Nucl Med Mol Imaging 2003, 30:1155-1159.

76. Moncayo R, Moncayo $\mathrm{H}$ : A musculoskeletal model of low grade connective tissue inflammation in patients with thyroid associated ophthalmopathy (TAO): the WOMED concept of lateral tension and its general implications in disease. BMC Musculoskelet Disord 2007, 8:17.

77. Liu Y, Yang J, Cai Z: Chemical investigation on Sijunzi decoction and its two major herbs Panax ginseng and Glycyrrhiza uralensis by LC/MS/MS. J Pharm Biomed Anal 2006, 41:1642-1647.

78. Liu Q, Cai G: [Content of somatostatin and cholecystokinin-8 in hypothalamus and colons in a rat model of spleen-deficiency syndrome]. Zhong Xi Yi Jie He Xue Bao 2007, 5:555-558.

79. Ross J: Combining western herbs and chinese medicine. Principles, practice \& materia medica. 1 edition. Seattle: Greenfields Press; 2003.

80. Bohlmann J, Lins T, Martin W, Eilert U: Anthranilate synthase from Ruta graveolens. Duplicated AS alpha genes encode tryptophan-sensitive and tryptophan-insensitive isoenzymes specific to amino acid and alkaloid biosynthesis. Plant Physiol 1996, 111:507-514.

81. Panossian A, Wagner $\mathrm{H}$ : Stimulating effect of adaptogens: an overview with particular reference to their efficacy following single dose administration. Phytother Res 2005, 19:819-838.

82. Bystrov NS, Dobrynin VN, Kolosov MN, Chernov BK, Chervin II: [Structure of the chromophoric part of hyperforin]. Dokl Akad Nauk SSSR 1975, 225:1327-1328.

83. Zeng JZ, Sun DF, Wang L, Cao X, Qi JB, Yang T, et al: Hypericum sampsonii induces apoptosis and nuclear export of retinoid $X$ receptor-alpha. Carcinogenesis 2006, 27:1991-2000.

84. Medina MA, Martinez-Poveda B, Amores-Sanchez MI, Quesada AR: Hyperforin: more than an antidepressant bioactive compound? Life Sci 2006, 79:105-111.

85. Wirz A, Simmen U, Heilmann J, Calis I, Meier B, Sticher O: Bisanthraquinone glycosides of Hypericum perforatum with binding inhibition to $\mathrm{CRH}-1$ receptors. Phytochemistry 2000, 55:941-947.

86. Beerhues L: Hyperforin. Phytochemistry 2006, 67:2201-2207.

87. Dell'Aica I, Caniato R, Biggin S, Garbisa S: Matrix proteases, green tea, and St. John's wort: biomedical research catches up with folk medicine. Clin Chim Acta 2007, 381:69-77.

88. Yarnell E: Botanical medicines for the urinary tract. World J Urol 2002, 20:285-293.

89. Chiu PY, Ko KM: Schisandrin B-induced increase in cellular glutathione level and protection against oxidant injury are mediated by the enhancement of glutathione synthesis and regeneration in AML12 and H9c2 cells. Biofactors 2006, 26:221-230.

90. Choi SI, Park SR, Heo TR: Matrix degradation inhibitory effect of Schisandra fructus on human articular cartilage and chondrocytes. J Ethnopharmacol 2006, 106:279-284.

91. Mu Y, Zhang J, Zhang S, Zhou HH, Toma D, Ren S, et al: Traditional Chinese medicines Wu Wei Zi (Schisandra chinensis Baill) and Gan Cao (Glycyrrhiza uralensis Fisch) activate pregnane $X$ receptor and increase warfarin clearance in rats. J Pharmacol Exp Ther 2006, 316:1369-1377.

92. Kou J, Sun Y, Lin Y, Cheng Z, Zheng W, Yu B, et al: Anti-inflammatory activities of aqueous extract from Radix Ophiopogon japonicus and its two constituents. Biol Pharm Bull 2005, 28:1234-1238.

93. Ko KM, Leung HY: Enhancement of ATP generation capacity, antioxidant activity and immunomodulatory activities by Chinese Yang and Yin tonifying herbs. Chin Med 2007, 2:3.

94. Nurtjahja-Tjendraputra E, Ammit AJ, Roufogalis BD, Tran VH, Duke CC: Effective anti-platelet and COX-1 enzyme inhibitors from pungent constituents of ginger. Thromb Res 2003, 111:259-265.

95. Chrubasik S, Pittler MH, Roufogalis BD: Zingiberis rhizoma: a comprehensive review on the ginger effect and efficacy profiles. Phytomedicine 2005, 12:684-701.

96. Grzanna R, Lindmark L, Frondoza CG: Ginger-an herbal medicinal product with broad anti-inflammatory actions. J Med Food 2005, 8:125-132.

97. Lantz RC, Chen GJ, Sarihan M, Solyom AM, Jolad SD, Timmermann BN: The effect of extracts from ginger rhizome on inflammatory mediator production. Phytomedicine 2007, 14:123-128. 
98. Roth BL: Receptor systems: will mining the receptorome yield novel targets for pharmacotherapy? Pharmacol Ther 2005, 108:59-64.

99. Roth BL, Lopez E, Beischel S, Westkaemper RB, Evans JM: Screening the receptorome to discover the molecular targets for plant-derived psychoactive compounds: a novel approach for CNS drug discovery. Pharmacol Ther 2004, 102:99-110.

100. Sucher NJ: Insights from molecular investigations of traditional Chinese herbal stroke medicines: implications for neuroprotective epilepsy therapy. Epilepsy Behav 2006, 8:350-362.

101. Straube A, Aicher B, Fiebich BL, Haag G: Combined analgesics in (headache) pain therapy: shotgun approach or precise multi-target therapeutics? BMC Neurol 2011, 11:43

102. Naito T, Itoh H, Yasunaga F, Takeyama M: Rikkunshi-to raises levels of somatostatin and gastrin in human plasma. Biol Pharm Bull 2001, 24:841-843.

103. Hu J, Wang Q, Liang W: [Effects of bushen yizhi recipe on somatostatinlike immunopositive and somatostatin messenger ribonucleic acid expressed-positive neurons in Alzheimer's disease model rats]. Zhongguo Zhong Xi Yi Jie He Za Zhi 2000, 20:533-535.

104. Naito T, Itoh H, Yasunaga F, Takeyama M: Hange-shashin-to raises levels of somatostatin, motilin, and gastrin in the plasma of healthy subjects. Biol Pharm Bull 2002, 25:327-331.

105. Gong Z, Yuan Y, Lou K, Tu S, Zhai Z, Xu J: Mechanisms of Chinese herb emodin and somatostatin analogs on pancreatic regeneration in acute pancreatitis in rats. Pancreas 2002, 25:154-160.

106. Katagiri F, Itoh H, Takeyama M: Effect of Sho-hange-ka-bukuryo-to on gastrointestinal peptide concentrations in the plasma of healthy human subjects. Biol Pharm Bull 2004, 27:1674-1678

107. Naito T, Itoh H, Nagano T, Takeyama M: Effects of Ninjin-to on levels of brain-gut peptides (motilin, vasoactive intestinal peptide, gastrin, and somatostatin) in human plasma. Biol Pharm Bull 2001, 24:194-196.

108. Naito T, Itoh H, Takeyama M: Effects of Hange-koboku-to (Banxia-houpotang) on neuropeptide levels in human plasma and saliva. Biol Pharm Bull 2003, 26:1609-1613.

109. Hiruma-Lima CA, Calvo TR, Rodrigues CM, Andrade FD, Vilegas W, Brito AR: Antiulcerogenic activity of Alchornea castaneaefolia: effects on somatostatin, gastrin and prostaglandin. J Ethnopharmacol 2006, 104:215-224.

110. Katagiri $F$, Inoue $S$, Itoh $H$, Takeyama M: Omeprazole raises somatostatin and motilin in human plasma. Biol Pharm Bull 2005, 28:370-373.

111. Pelley RJ, Bukowski RM: Recent advances in diagnosis and therapy of neuroendocrine tumors of the gastrointestinal tract. Curr Opin Oncol 1997, 9:68-74

112. Marchese A, Heiber $M$, Nguyen $T$, Heng HH, Saldivia VR, Cheng $R$, et al: Cloning and chromosomal mapping of three novel genes, GPR9, GPR10, and GPR14, encoding receptors related to interleukin 8, neuropeptide Y, and somatostatin receptors. Genomics 1995, 29:335-344.

113. Mori M, Sugo T, Abe M, Shimomura $Y$, Kurihara M, Kitada $C$, et al: Urotensin II is the endogenous ligand of a G-protein-coupled orphan receptor, SENR (GPR14). Biochem Biophys Res Commun 1999, 265:123-129.

114. Malagon MM, Molina M, Gahete MD, Duran-Prado M, Martinez-Fuentes AJ, Alcain FJ, et al: Urotensin II and urotensin II-related peptide activate somatostatin receptor subtypes 2 and 5. Peptides 2008, 29:711-720.

115. Tostivint H, Lihrmann I, Vaudry H: New insight into the molecular evolution of the somatostatin family. Mol Cell Endocrinol 2008, 286:5-17.

116. Cordoba-Chacon J, Gahete MD, Durán-Prado M, Pozo-Salas Al Malagón MM, Gracia-Navarro F, et al: Identification and characterization of new functional truncated variants of somatostatin receptor subtype 5 in rodents. Cell Mol Life Sci 2010, 67:1147-1163.

117. Samson WK, Zhang JV, Avsian-Kretchmer O, Cui K, Yosten GL, Klein C, et al: Neuronostatin encoded by the somatostatin gene regulates neuronal, cardiovascular, and metabolic functions. J Biol Chem 2008, 283:31949-31959.

118. Allia E, Tarabra E, Volante M, Cerrato M, Ghigo E, Muccioli G, et al: Expression of cortistatin and MrgX2, a specific cortistatin receptor, in human neuroendocrine tissues and related tumours. J Pathol 2005, 207:336-345.

119. Volante M, Rosas R, Allia E, Granata R, Baragli A, Muccioli G, et al: Somatostatin, cortistatin and their receptors in tumours. Mol Cell Endocrinol 2008, 286:219-229.
120. Yang S, Liu Y, Lin AA, Cavalli-Sforza LL, Zhao Z, Su B: Adaptive evolution of MRGX2, a human sensory neuron specific gene involved in nociception. Gene 2005, 352:30-35.

121. Robas N, Mead E, Fidock M: MrgX2 is a high potency cortistatin receptor expressed in dorsal root ganglion. J Biol Chem 2003, 278:44400-44404.

122. Ferone D, Boschetti M, Resmini E, Giusti M, Albanese $V$, Goglia U, et al: Neuroendocrine-immune interactions: the role of cortistatin/ somatostatin system. Ann N Y Acad Sci 2006, 1069:129-144.

123. de Lecea L, Criado JR, Prospero-Garcia O, Gautvik KM, Schweitzer P, Danielson PE, et al: A cortical neuropeptide with neuronal depressant and sleep-modulating properties. Nature 1996, 381:242-245.

124. Fukusumi S, Kitada C, Takekawa S, Kizawa H, Sakamoto J, Miyamoto M, et al: Identification and characterization of a novel human cortistatin-like peptide. Biochem Biophys Res Commun 1997, 232:157-163.

125. Wreggett KA, Wells JW: Cooperativity manifest in the binding properties of purified cardiac muscarinic receptors. J Biol Chem 1995, 270:22488-22499.

126. Birnbaumer L, Abramowitz J, Brown AM: Receptor-effector coupling by G proteins. Biochim Biophys Acta 1990, 1031:163-224

127. Gouldson PR, Snell CR, Bywater RP, Higgs C, Reynolds CA: Domain swapping in G-protein coupled receptor dimers. Protein Eng 1998 11:1181-1193.

128. Takesono A, Cismowski MJ, Ribas C, Bernard M, Chung P, Hazard S III, et al: Receptor-independent activators of heterotrimeric G-protein signaling pathways. J Biol Chem 1999, 274:33202-33205

129. Lefkowitz RJ: The superfamily of heptahelical receptors. Nat Cell Biol 2000, 2:E133-E136

130. Rios CD, Jordan BA, Gomes I, Devi LA: G-protein-coupled receptor dimerization: modulation of receptor function. Pharmacol Ther 2001 92:71-87.

131. Fredriksson R, Lagerström MC, Lundin LG, Schiöth HB: The G-proteincoupled receptors in the human genome form five main families. Phylogenetic analysis, paralogon groups, and fingerprints. Mol Pharmacol 2003, 63:1256-1272.

132. Fredriksson R, Schiöth HB: The repertoire of G-protein-coupled receptors in fully sequenced genomes. Mol Pharmacol 2005, 67:1414-1425.

133. Javitch JA: The ants go marching two by two: oligomeric structure of Gprotein-coupled receptors. Mol Pharmacol 2004, 66:1077-1082.

134. Skrabanek L, Murcia M, Bouvier M, Devi L, George SR, Lohse MJ, et al: Requirements and ontology for a G protein-coupled receptor oligomerization knowledge base. BMC Bioinformatics 2007, 8:177.

135. Agnati LF, Fuxe K, Zini I, Lenzi P, Hökfelt T: Aspects on receptor regulation and isoreceptor identification. Med Biol 1980, 58:182-187.

136. Reggio $\mathrm{PH}$ : Computational methods in drug design: modeling $\mathrm{G}$ proteincoupled receptor monomers, dimers, and oligomers. AAPS J 2006, 8: E322-E336.

137. Agnati LF, Fuxe KG, Goncharova LB, Tarakanov AO: Receptor mosaics of neural and immune communication: Possible implications for basal ganglia functions. Brain Res Rev 2007, 58:400-414.

138. Fuxe K, Canals M, Torvinen M, Marcellino D, Terasmaa A, Genedani S, et al Intramembrane receptor-receptor interactions: a novel principle in molecular medicine. J Neural Transm 2007, 114:49-75.

139. Fuxe K, Marcellino D, Rivera A, Diaz-Cabiale Z, Filip M, Gago B, et al: Receptor-receptor interactions within receptor mosaics. Impact on neuropsychopharmacology. Brain Res Rev 2008, 58:415-452.

140. Durroux T: Principles: a model for the allosteric interactions between ligand binding sites within a dimeric GPCR. Trends Pharmacol Sci 2005 26:376-384.

141. Giraldo J: On the fitting of binding data when receptor dimerization is suspected. Br J Pharmacol 2008, 155:17-23.

142. Rovira X, Pin JP, Giraldo J: The asymmetric/symmetric activation of GPCR dimers as a possible mechanistic rationale for multiple signalling pathways. Trends Pharmacol Sci 2010, 31:15-21.

143. Salahpour A, Angers S, Bouvier M: Functional significance of oligomerization of G-protein-coupled receptors. Trends Endocrinol Metab 2000, 11:163-168.

144. Lundstrom K: Structural genomics of GPCRs. Trends Biotechnol 2005, 23:103-108.

145. Rocheville M, Lange DC, Kumar U, Sasi R, Patel RC, Patel YC: Subtypes of the somatostatin receptor assemble as functional homo- and heterodimers. J Biol Chem 2000, 275:7862-7869. 
146. Hukovic N, Rocheville M, Kumar U, Sasi R, Khare S, Patel YC: Agonistdependent up-regulation of human somatostatin receptor type 1 requires molecular signals in the cytoplasmic C-tail. J Biol Chem 1999, 274:24550-24558.

147. Tannenbaum GS, Turner J, Guo F, Videau C, Epelbaum J, Beaudet A: Homologous upregulation of sst2 somatostatin receptor expression in the rat arcuate nucleus in vivo. Neuroendocrinology 2001, 74:33-42.

148. Pfeiffer M, Koch T, Schröder H, Klutzny M, Kirscht S, Kreienkamp HJ, et al: Homo- and heterodimerization of somatostatin receptor subtypes. Inactivation of sst(3) receptor function by heterodimerization with sst (2A). J Biol Chem 2001, 276:14027-14036.

149. Grant M, Collier B, Kumar U: Agonist-dependent dissociation of human somatostatin receptor 2 dimers: a role in receptor trafficking. $J$ Biol Chem 2004, 279:36179-36183.

150. Jacobs S, Schulz S: Intracellular trafficking of somatostatin receptors. Mol Cell Endocrinol 2007, 286:58-62.

151. Durán-Prado M, Malagón MM, Gracia-Navarro F, Castaño JP: Dimerization of $\mathrm{G}$ protein-coupled receptors: New avenues for somatostatin receptor signalling, control and functioning. Mol Cell Endocrinol 2008, 286:63-68.

152. Reubi JC, Erchegyi J, Cescato R, Waser B, Rivier JE: Switch from antagonist to agonist after addition of a DOTA chelator to a somatostatin analog. Eur J Nucl Med Mol Imaging 2010, 37:1551-1558.

153. Rocheville M, Lange DC, Kumar U, Patel SC, Patel RC, Patel YC: Receptors for dopamine and somatostatin: formation of hetero-oligomers with enhanced functional activity. Science 2000, 288:154-157.

154. Pfeiffer M, Koch T, Schröder H, Laugsch M, Höllt V, Schulz S: Heterodimerization of somatostatin and opioid receptors crossmodulates phosphorylation, internalization, and desensitization. J Biol Chem 2002, 277:19762-19772.

155. Pfeiffer M, Kirscht S, Stumm R, Koch T, Wu D, Laugsch M, et al: Heterodimerization of substance $P$ and mu-opioid receptors regulates receptor trafficking and resensitization. J Biol Chem 2003, 278:51630-51637.

156. Gomes I, Jordan BA, Gupta A, Trapaidze N, Nagy V, Devi LA Heterodimerization of mu and delta opioid receptors: $A$ role in opiate synergy. J Neurosci 2000, 20:RC110.

157. Gloriam DE, Fredriksson R, Schiöth HB: The G protein-coupled receptor subset of the rat genome. BMC Genomics 2007, 8:338.

158. Kenakin TP: '7TM receptor allostery: putting numbers to shapeshifting proteins. Trends Pharmacol Sci 2009, 30:460-469.

159. O'Toole D, Saveanu A, Couvelard A, Gunz G, Enjalbert A, Jaquet P, et al: The analysis of quantitative expression of somatostatin and dopamine receptors in gastro-entero-pancreatic tumours opens new therapeutic strategies. Eur J Endocrinol 2006, 155:849-857.

160. Ferone D, Saveanu A, Culler MD, Arvigo M, Rebora A, Gatto F, et al: Novel chimeric somatostatin analogs: facts and perspectives. Eur J Endocrinol 2007, 156(Suppl 1):S23-S28.

161. Arvigo M, Gatto F, Ruscica M, Ameri P, Dozio E, Albertelli M, et al: Somatostatin and dopamine receptor interaction in prostate and lung cancer cell lines. J Endocrinol 2010, 207:309-317.

162. Oakley RH, Laporte SA, Holt JA, Caron MG, Barak LS: Differential affinities of visual arrestin, beta arrestin1, and beta arrestin2 for $\mathrm{G}$ proteincoupled receptors delineate two major classes of receptors. J Biol Chem 2000, 275:17201-17210.

163. Ma L, Pei G: Beta-arrestin signaling and regulation of transcription. J Cell Sci 2007, 120:213-218.

164. Kang J, Shi Y, Xiang B, Qu B, Su W, Zhu M, et al: A nuclear function of beta-arrestin1 in GPCR signaling: regulation of histone acetylation and gene transcription. Cell 2005, 123:833-847.

165. Storez H, Scott MG, Issafras H, Burtey A, Benmerah A, Muntaner O, et al: Homo- and hetero-oligomerization of beta-arrestins in living cells. J Biol Chem 2005, 280:40210-40215.

166. Tulipano G, Stumm R, Pfeiffer M, Kreienkamp HJ, Höllt V, Schulz S: Differential beta-arrestin trafficking and endosomal sorting of somatostatin receptor subtypes. J Biol Chem 2004, 279:21374-21382.

167. Tulipano G, Schulz S: Novel insights in somatostatin receptor physiology. Eur J Endocrinol 2007, 156(Suppl 1):S3-S11

168. Ramirez JL, Watt HL, Rocheville M, Kumar U: Agonist-induced upregulation of human somatostatin receptor type 1 is regulated by betaarrestin-1 and requires an essential serine residue in the receptor C-tail. Biochim Biophys Acta 2005, 1669:182-192.
169. Parameswaran N, Spielman WS: RAMPs: The past, present and future. Trends Biochem Sci 2006, 31:631-638.

170. Anderson RG: The caveolae membrane system. Annu Rev Biochem 1998, 67:199-225.

171. Chini B, Parenti M: G-protein coupled receptors in lipid rafts and caveolae: how, when and why do they go there? J Mol Endocrinol 2004 32:325-338.

172. Oh P, Schnitzer JE: Segregation of heterotrimeric $G$ proteins in cell surface microdomains. $\mathrm{G}(\mathrm{q})$ binds caveolin to concentrate in caveolae, whereas $\mathrm{G}(\mathrm{i})$ and $\mathrm{G}(\mathrm{s})$ target lipid rafts by default. Mol Biol Cell 2001, 12:685-698.

173. Ostrom RS, Insel PA: The evolving role of lipid rafts and caveolae in G protein-coupled receptor signaling: implications for molecular pharmacology. Br J Pharmacol 2004, 143:235-245.

174. Xu W, Yoon SI, Huang P, Wang Y, Chen C, Chong PL, et al: Localization of the kappa opioid receptor in lipid rafts. J Pharmacol Exp Ther 2006, 317:1295-1306

175. Harikumar KG, Puri V, Singh RD, Hanada K, Pagano RE, Miller LJ: Differential effects of modification of membrane cholesterol and sphingolipids on the conformation, function, and trafficking of the $\mathrm{G}$ protein-coupled cholecystokinin receptor. J Biol Chem 2005, 280:2176-2185.

176. Gouldson PR, Dean MK, Snell CR, Bywater RP, Gkoutos G, Reynolds CA: Lipid-facing correlated mutations and dimerization in G-protein coupled receptors. Protein Eng 2001, 14:759-767.

177. Sjögren B, Hamblin MW, Svenningsson P: Cholesterol depletion reduces serotonin binding and signaling via human $5-\mathrm{HT} 7$ (a) receptors. Eur J Pharmacol 2006, 552:1-10.

178. Garcia JJ, Martinez-Ballarin E, Millan-Plano S, Allue JL, Albendea C, Fuentes L, et al: Effects of trace elements on membrane fluidity. J Trace Elem Med Biol 2005, 19:19-22

179. Dobretsov GE, Borschevskaya TA, Petrov VA, Vladimirov YA: The increase of phospholipid bilayer rigidity after lipid peroxidation. FEBS Lett 1977, 84:125-128.

180. Van der Vliet A, Bast A: Effect of oxidative stress on receptors and signal transmission. Chem Biol Interact 1992, 85:95-116.

181. Borst JW, Visser NV, Kouptsova O, Visser AJ: Oxidation of unsaturated phospholipids in membrane bilayer mixtures is accompanied by membrane fluidity changes. Biochim Biophys Acta 2000, 1487:61-73.

182. Moncayo R, Traeger A: Decreased selenium levels after Peptide Receptor Radionuclide Therapy (PRRT) in patients with neuroendocrine tumors: Implications for the antioxidant status. Eur J Nucl Med Mol Imaging 2011 38:1580-1581.

183. Michiels C, Raes M, Toussaint O, Remacle J: Importance of Se-glutathione peroxidase, catalase, and $\mathrm{Cu} / \mathrm{Zn}-\mathrm{SOD}$ for cell survival against oxidative stress. Free Radic Biol Med 1994, 17:235-248.

184. Diplock AT, Charleux JL, Crozier-Willi G, Kok FJ, Rice-Evans C, Roberfroid M, et al: Functional food science and defence against reactive oxidative species. Br J Nutr 1998, 80(Suppl 1):S77-112

185. Patel HH, Murray F, Insel PA: Caveolae as organizers of pharmacologically relevant signal transduction molecules. Annu Rev Pharmacol Toxicol 2008, 48:359-391.

186. Goetz JG, Lajoie P, Wiseman SM, Nabi IR: Caveolin-1 in tumor progression: the good, the bad and the ugly. Cancer Metastasis Rev 2008, 27:715-735.

187. Nakakura EK, Sriuranpong VR, Kunnimalaiyaan M, Hsiao EC, Schuebel KE, Borges MW, et al: Regulation of neuroendocrine differentiation in gastrointestinal carcinoid tumor cells by notch signaling. J Clin Endocrinol Metab 2005, 90:4350-4356.

188. Kunnimalaiyaan M, Vaccaro AM, Ndiaye MA, Chen $\mathrm{H}$ : Inactivation of glycogen synthase kinase-3beta, a downstream target of the raf-1 pathway, is associated with growth suppression in medullary thyroid cancer cells. Mol Cancer Ther 2007, 6:1151-1158.

189. Pinchot SN, Pitt SC, Sippel RS, Kunnimalaiyaan M, Chen H: Novel targets for the treatment and palliation of gastrointestinal neuroendocrine tumors. Curr Opin Investig Drugs 2008, 9:576-582.

190. Potter JD: Morphostats: a missing concept in cancer biology. Cancer Epidemiol Biomarkers Prev 2001, 10:161-170.

191. Potter JD: Morphogens, morphostats, microarchitecture and malignancy. Nat Rev Cancer 2007, 7:464-474

192. Baker SG, Soto AM, Sonnenschein C, Cappuccio A, Potter JD, Kramer BS: Plausibility of stromal initiation of epithelial cancers without a mutation 
in the epithelium: a computer simulation of morphostats. BMC Cancer 2009, 9:89.

193. Benjamin M: The fascia of the limbs and back-a review. J Anat 2009, 214:1-18.

194. Gerlach UJ, Lierse W: Functional construction of the superficial and deep fascia system of the lower limb in man. Acta Anat (Basel) 1990, 139:11-25.

195. Huijing PA: Epimuscular myofascial force transmission: a historical review and implications for new research. International Society of Biomechanics Muybridge Award Lecture, Taipei, 2007. J Biomech 2009, 42:9-21.

196. Wedeen VJ, Wang RP, Schmahmann JD, Benner T, Tseng WY, Dai G, et al: Diffusion spectrum magnetic resonance imaging (DSI) tractography of crossing fibers. Neuroimage 2008, 41:1267-1277.

197. Sosnovik DE, Wang R, Dai G, Wang T, Aikawa E, Novikov M, et al: Diffusion spectrum MRI tractography reveals the presence of a complex network of residual myofibers in infarcted myocardium. Circ Cardiovasc Imaging 2009, 2:206-212.

198. Sosnovik DE, Wang R, Dai G, Reese TG, Wedeen VJ: Diffusion MR tractography of the heart. J Cardiovasc Magn Reson 2009, 11:47.

199. Standerwick RG, Roberts WE: The aponeurotic tension model of craniofacial growth in man. Open Dent J 2009, 3:100-113.

200. Becker RF: The meaning of fascia and fascial continuity. Osteopath Ann 1975, 3:8-32.

201. Cooper GJ: Some clinical considerations on fascia in diagnosis and treatment. J Am Osteopath Assoc 1979, 78:336-347.

202. Vazquez Botet M, Sanchez JL: The fascia in systemic scleroderma. J Am Acad Dermatol 1980, 3:36-42.

203. Strosser MT, Scala-Guenot D, Koch B, Mialhe P: Inhibitory effect and mode of action of somatostatin on lipolysis in chicken adipocytes. Biochim Biophys Acta 1983, 763:191-196.

204. Simon MA, Romero B, Calle C: Characterization of somatostatin binding sites in isolated rat adipocytes. Regul Pept 1988, 23:261-270.

205. Seboek D, Linscheid P, Zulewski H, Langer I, Christ-Crain M, Keller U, et al: Somatostatin is expressed and secreted by human adipose tissue upon infection and inflammation. J Clin Endocrinol Metab 2004, 89:4833-4839.

206. Durán-Prado M, Gahete MD, Martínez-Fuentes AJ, Luque RM, Quintero A, Webb SM, et al: Identification and characterization of two novel truncated but functional isoforms of the somatostatin receptor subtype 5 differentially present in pituitary tumors. J Clin Endocrinol Metab 2009, 94:2634-2643.

207. Córdoba-Chacón J, Gahete MD, Durán-Prado M, Pozo-Salas Al, Malagón MM, Gracia-Navarro F, et al: Identification and characterization of new functional truncated variants of somatostatin receptor subtype 5 in rodents. Cell Mol Life Sci 2010, 67:1147-1163.

208. Córdoba-Chacón J, Gahete MD, Durán-Prado M, Luque RM, Castaño JP: Truncated somatostatin receptors as new players in somatostatincortistatin pathophysiology. Ann N Y Acad Sci 2011, 1220:6-15.

209. Durán-Prado M, Saveanu A, Luque RM, Gahete MD, Gracia-Navarro F, Jaquet $P$, et al: A potential inhibitory role for the new truncated variant of somatostatin receptor 5 , sst5TMD4, in pituitary adenomas poorly responsive to somatostatin analogs. J Clin Endocrinol Metab 2010, 95:2497-2502.

210. Rens-Domiano S, Reisine T: Structural analysis and functional role of the carbohydrate component of somatostatin receptors. J Biol Chem 1991, 266:20094-20102.

211. Møller LN, Stidsen CE, Hartmann B, Holst JJ: Somatostatin receptors. Biochim Biophys Acta 2003, 1616:1-84.

212. Helboe L, Møller M, Nørregaard L, Schiødt M, Stidsen CE: Development of selective antibodies against the human somatostatin receptor subtypes sst1-sst5. Brain Res Mol Brain Res 1997, 49:82-88.

213. Colao A, Auriemma RS, Lombardi G, Pivonello R: Resistance to somatostatin analogs in acromegaly. Endocr Rev 2011, 32:247-271.

214. Ur E, Bomanji J, Mather SJ, Britton KE, Wass JA, Grossman AB, et al: Localization of neuroendocrine tumours and insulinomas using radiolabelled somatostatin analogues, 1231-Tyr3-octreotide and 111/npentatreotide. Clin Endocrinol 1993, 38:501-506.

215. Gahete MD, Córdoba-Chacón J, Durán-Prado M, Malagón MM, MartínezFuentes AJ, Gracia-Navarro F, et al: Somatostatin and its receptors from fish to mammals. Ann N Y Acad Sci 2010, 1200:43-52.

216. Vaudry H, Do Rego JC, Le Mevel JC, Chatenet D, Tostivint H, Fournier A, et al: Urotensin II, from fish to human. Ann N Y Acad Sci 2010, 1200:53-66.
217. Djerassi C: Chemical birth of the pill. 1992. Am J Obstet Gynecol 2006, 194:290-298

218. Erren TC, Falaturi P: Research insights and insides:"Science-in-Fiction" as a contribution to the Third Culture Concepts. Med Hypotheses 2009, 72:487-490.

219. Freezer LW: Theories concerning the causation of disease. Am J Public Health 1921, 11:908-912.

220. Rodin AE: A historical survey of disease concepts. Can Med Assoc J 1962, 87:124-128.

221. Hill AB: The environment and disease: association or causation? Proc $R$ Soc Med 1965, 58:295-300.

222. Bessinger CD Jr: Doctoring: the philosophic milieu. South Med J 1988, 81:1558-1562.

223. Rizzi DA: Causal reasoning and the diagnostic process. Theor Med 1994, 15:315-333.

224. Black N: Why we need observational studies to evaluate the effectiveness of health care. BMJ 1996, 312:1215-1218.

225. Atkins D, Best D, Briss PA, Eccles M, Falck-Ytter Y, Flottorp S, et al: Grading quality of evidence and strength of recommendations. BMJ 2004, 328:1490.

226. Grimes DA, Schulz KF: Compared to what? Finding controls for casecontrol studies. Lancet 2005, 365:1429-1433.

227. Coalition chess by Arnold Schoenberg. 2010, Ref Type: Internet Communication.

228. Haberkorn U, Altmann A, Mier W, Eisenhut M: Impact of functional genomics and proteomics on radionuclide imaging. Semin Nucl Med 2004, 34:4-22.

229. Fuchs D, Winkelmann I, Johnson IT, Mariman E, Wenzel U, Daniel H: Proteomics in nutrition research: principles, technologies and applications. Br J Nutr 2005, 94:302-314.

230. van der HE, Peironcely JE, ljzerman AP, Beukers MW, Lane JR, van Vlijmen HW, et al: A novel chemogenomics analysis of G protein-coupled receptors (GPCRs) and their ligands: a potential strategy for receptor deorphanization. BMC Bioinformatics 2010, 11:316.

231. Kell DB: Theodor Bucher Lecture. Metabolomics, modelling and machine learning in systems biology-towards an understanding of the languages of cells. Delivered on 3 July 2005 at the 30th FEBS Congress and the 9th IUBMB conference in Budapest. FEBS J 2006, 273:873-894.

232. Fenech MF: Nutriomes and nutrient arrays-the key to personalised nutrition for DNA damage prevention and cancer growth control. Genome Integr 2010, 1:11.

233. Agnati LF, Guidolin D, Vilardaga JP, Ciruela F, Fuxe K: On the expanding terminology in the GPCR field: the meaning of receptor mosaics and receptor heteromers. J Recept Signal Transduct Res 2010, 30:287-303.

234. Fuxe K, Marcellino D, Borroto-Escuela DO, Frankowska M, Ferraro L, Guidolin $D$, et al: The changing world of $G$ protein-coupled receptors: from monomers to dimers and receptor mosaics with allosteric receptor-receptor interactions. J Recept Signal Transduct Res 2010, 30:272-283.

235. Helm CL, Fleury ME, Zisch AH, Boschetti F, Swartz MA: Synergy between interstitial flow and VEGF directs capillary morphogenesis in vitro through a gradient amplification mechanism. Proc Natl Acad Sci USA 2005, 102:15779-15784.

236. Hofsli E, Thommesen L, Yadetie F, Langaas M, Kusnierczyk W, Falkmer U, et al: Identification of novel growth factor-responsive genes in neuroendocrine gastrointestinal tumour cells. Br J Cancer 2005, 92:1506-1516.

237. Shraiman BI: Mechanical feedback as a possible regulator of tissue growth. Proc Natl Acad Sci USA 2005, 102:3318-3323.

238. Izquierdo-Kulich E, Nieto-Villar JM: Morphogenesis of the tumor patterns. Math Biosci Eng 2008, 5:299-313.

239. Wartlick O, Kicheva A, González-Gaitán M: Morphogen gradient formation. Cold Spring Harb Perspect Biol 2009, 1:a001255.

240. Aulehla A, Pourquié O: Signaling gradients during paraxial mesoderm development. Cold Spring Harb Perspect Biol 2010, 2:a000869.

241. Smith DJ, Query CC, Konarska MM: "Nought may endure but mutability": spliceosome dynamics and the regulation of splicing. Mol Cell 2008, 30:657-666.

242. Bombardieri E, Ambrosini V, Aktolun C, Baum RP, Bishof-Delaloye A, Del Vecchio $S$, et al: $111 \mathrm{ln}$-pentetreotide scintigraphy: procedure guidelines for tumour imaging. Eur J Nucl Med Mol Imaging 2010, 37:1441-1448. 
243. Virgolini I, Ambrosini V, Bomanji JB, Baum RP, Fanti S, Gabriel M, et al: Procedure guidelines for PET/CT tumour imaging with 68Ga-DOTAconjugated peptides: 68Ga-DOTA-TOC, 68Ga-DOTA-NOC, 68Ga-DOTATATE. Eur J Nucl Med Mol Imaging 2010, 37:2004-2010.

244. Castillo M: The Uncertainty of Science and the Science of Uncertainty. AJNR Am I Neuroradiol 2010, 31:1767-1768.

245. Feynman RP: The Uncertainty of Science. 2010 [http://www.inffu-berlin.de/ lehre/pmo/eng/Feynman-Uncertainty.pdf], Ref Type: Internet Communication.

doi:10.1186/2191-219X-1-9

Cite this article as: Moncayo: Reflections on the theory of "silver bullet" octreotide tracers: implications for ligand-receptor interactions in the age of peptides, heterodimers, receptor mosaics, truncated receptors, and multifractal analysis. EJNMMI Research 2011 1:9.

\section{Submit your manuscript to a SpringerOpen ${ }^{\circ}$ journal and benefit from:}

- Convenient online submission

- Rigorous peer review

- Immediate publication on acceptance

- Open access: articles freely available online

- High visibility within the field

- Retaining the copyright to your article

Submit your next manuscript at $\gg$ springeropen.com 